\title{
Gurda Motif in Batik Arrangement
}

\author{
Aan Sudarwanto ${ }^{1 *} \quad$ Sri Rochana W. ${ }^{2} \quad$ Dharsono $^{2}$ \\ 1.Arts Doctoral Program, Indonesian Institute of the Arts Surakarta \\ 2.Postgraduate of the Indonesian Institute of the Arts Surakarta
}

\begin{abstract}
This article that discusses Gurda motif aims to determine the structure and arrangement of Gurda motif in classical pattern batik. It is also to know more clearly how the shape of the Gurda motif on classical pattern batik that developed in Javanese society. The importance of the problem of the structure and variation of the Gurda motif raised in this article is based on the idea that the shape of the Gurda motif in batik does not appear suddenly but has undergone a long journey. This can be known by tracing past cultural results, both with mental facts and from existing artefacts. This writing is very important because it will reveal more clearly how the existence of the Gurda motif in the structure and arrangement of batik so that it is hoped that the essence behind the motif will emerge. The method used is in the form of interactive analysis, which is a flowing relationship of three main components, namely data reduction, data presentation and concluding, with activities carried out interactively, then followed by the process of collecting data repeatedly so that it takes the form of a cycle. This research is hermeneutic qualitative research that emphasizes the interpretation of meaningful expressions. In this research, there may be an interpretation of the interpretation that has been done by community groups to reinterpret it as a cultural phenomenon, in this case, the gurda motive with its various complexities.
\end{abstract}

Keywords: Gurda motif, structure, essence.

DOI: $10.7176 / \mathrm{ADS} / 91-03$

Publication date:March $31^{\text {st }} 2021$

\section{INTRODUCTION}

Motifs are visual strokes that are beautifully arranged to sweeten an object so that they have more appeal, and can give off an aura of grandeur and an impression of grace. The definition of the motif is part of a pattern, which if duplicated or given certain variations by repetition becomes a pattern. (Kenneth F. Bates, 1986: 33) explains in more detail by Fowler that motive is a constituent feature (main element) and dominant idea in artistic composition (main idea in artistic composition). (H.J. Fowler and F.G. Fowler., 1964: 788) From this explanation, it can be seen that the motif is the most prominent or dominant element in the arrangement of a pattern, where the motif is used as the base to create the pattern. The same thought was also expressed by Tukiyo and Sukarman as follows:

The motif can be interpreted as the main element in the art of ornament. It is the basic form in the creation or embodiment of ornament forms.... Whereas the pattern implies an arrangement or organization of certain motifs in certain forms and compositions (Tokiyo and Sukarman, 1981: 3).

Based on these thoughts, the motif is the main element of an ornament that has the power to make an object have more value. This also happens to batik motifs, which are always interesting to study and develop, partly because batik motifs can give off an aura of grandeur and grace to the wearer. There are many kinds of batik motifs, one of the motifs that attract attention to be studied is the Gurda motif. A motif depicting a Garuda ${ }^{1}$. Gurda can be said to be a motif depicted in the form of a bird with two broad left and right wings and a long tail in the middle. (J.E. Jasper and Mas Pirngadie, 1916: 184) It is a form that depicts a stylized eagle, usually, a gurda cannot stand alone as a batik pattern but is the main motif in a batik pattern. The placement of Gurda motifs in batik patterns is often used in semen, lereng and ceplok batik patterns. The stylization shape of the Garuda has many variations, but in general, Sewan Susanto identifies it into six types (Susanto, 1980: 266). Of the six types, there is one that is described as the most complete, which is known as sawat. What is meant by sawat is a picture in the form of right and left wings and has a tail that symbolizes the eagle. All batik patterns that contain images of sawat are included in the batik class that can only be used by certain kings and aristocrats during the Kasunanan Kraton Surakarta, including the batik with the semen gedhe $e^{2}$ pattern. Based on this, it can be seen how interesting the theme of this Gurda motif is as research material, of course, it is related to the natural thinking of the Javanese people in the past by exploring the shape of the Gurda motif in the structure and

\footnotetext{
${ }^{1}$ Garuda is a mythological creature that has been known through ancient mythology in the history of the Indonesian nation, namely the Vishnu vehicle which resembles an eagle. Garuda is used as a State Symbol to illustrate that Indonesia is a great nation and a strong country. Apart from being used as the symbol of the Indonesian state, Garuda is also often found in various attributes of historical heritage objects. The Garuda ornament was originally dedicated for religious purposes, then grew, developed in a wider form and function to meet human needs.

${ }^{2}$ Soerjanto, 2008 in Aan Sudarwanto, 2012, Batik dan Simbol Keagungan Raja (Batik and the Symbol of the Majesty of the King), Surakarta: LPKBN Citra Sain., P 63
} 
arrangement of batik.

The Gurda motive in the view of Javanese society has a high position, is used on honor clothes on certain occasions so that it cannot be denied that this motif certainly has deep and interesting symbolic philosophical value. The importance of this motif to be studied is based on considerations, among others, that the development of cultural dynamics and changes in people's mindset tends to pop culture and is instantaneous so that the Gurda motif is less well known to the public. Apart from that, Javanese clothes as everyday clothes are fading so that batik appears in a new form, therefore innovation is needed to adapt to the changes and developments of the era but still rooted in the same cultural sources.

\section{OBJECTIVES}

1.To find out the structure and arrangement of Gurda motifs in classical batik patterns.

2.To find out more clearly how the variations in the shape of the Gurda motif on the classical pattern of batik that developed in Javanese society.

\section{METHOD}

Based on the research objectives above, this research wants to explore and explain about a cultural phenomenon, especially about the structure and arrangement of Gurda motifs in classical batik so that its existence will be known. So the methodology that is most likely to be used in this study is a qualitative descriptive research method. The analysis uses interactive analysis which is a flowing relationship of three main components, namely data reduction, data presentation and concluding, with activities carried out interactively, then followed by a process of collecting data repeatedly so that it takes the form of a cycle. This research is hermeneutic qualitative research that emphasizes the interpretation of meaningful expressions. In this study, there may be an interpretation of the interpretation ${ }^{3}$ that has been carried out by community groups (Sutopo, 2006: 28) to reinterpret it as a cultural phenomenon, in this case, the Gurda motif on batik with its various complexities.

Meanwhile, the steps taken by the author in analyzing the problems of this research, among others, are preceded by grouping data sources that pay attention to their validity. The types of data sources that the authors use can be grouped, among others, sources, events/activities, locations, objects/images, and documents/archives. Then an analysis of the relationship flows from the three main components, namely data reduction, data presentation and drawing conclusions, whose activities are carried out interactively, followed by a further data collection process so that it takes the form of a cycle. In summary, can be seen in the following chart.

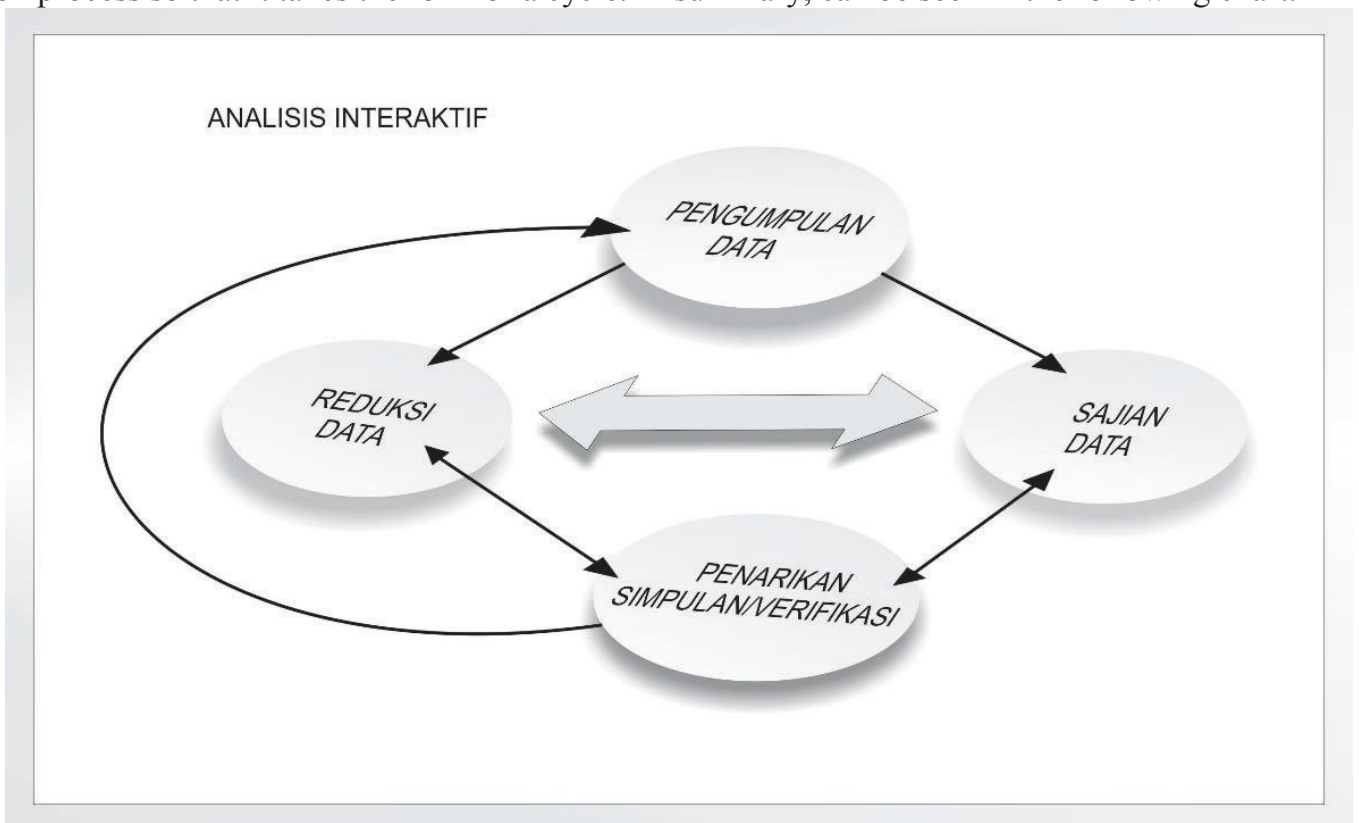

Picture 1. : Diagram of an interactive analysis model, the continuous analysis process is cycle-shaped, the researcher moves between the three components of the analysis with the data collection process. (HB Sutopo, 2006: 119)

\footnotetext{
${ }^{3}$ Further, it can be seen in the book written by HB Sutopo 2006 pages 28-29 about qualitative research methodology, where it is explained that every event or work has a meaning from the interpretation of the actors or creators. The work or event which is an interpretation of something then faces the reader or observer, and is captured by interpretation as well. In other words, every work will always be recreated by the observer or get a new meaning created by the observer of the work.
} 


\section{LITERATURE REVIEW}

Several works of literature related will presented directly or indirectly to the theme to reveal similar studies so that the position of this research is known. Besides that, according to Leedy it can help provide an overview of the methods and techniques used in research that have similar problems to the research that the author is facing and also to show the position of research that the author will do in the history of development and the context of science or theory in which this research is located (Leedy, 1997: 71). And what is no less important is to prove the authenticity of the research, that the research conducted by the author is different from previous studies.

The libraries that the authors present include; An important book that is often used as a reference for writing very popular batik is the writing of Sewan Susanto, entitled, Seni Kerajinan Batik Indonesia (The Art of Indonesian Batik Crafts). The book contains a wide variety of issues about batik, from the manufacturing technique to the development of batik in Indonesia. The book also discusses the problem of reviewing batik motifs in various regions.

Although it is far from the research theme, it can at least give an overview of the history, namely Soedarmono's writing entitled "Munculnya Kelompok Pengusaha Batik di Laweyan Pada Awal Abad XX (The Emergence of Batik Entrepreneurs Groups in Laweyan at the Beginning of the XX Century)". This paper is a 1987 thesis from Gajah Mada University, Yogyakarta, which describes the sociological relationship of the batik craftsmen community in Surakarta, especially in the laweyan area in the early 20th century.

Other writings on batik are by Harmen C. Veldhuisen entitled, Batik Belanda 1840 - 1940 (Dutch Batik 1840 - 1940). This paper contains the Dutch influence on batik in Java, along with its history and stories; Apart from the aforementioned writings, there are other writings, either directly or indirectly related to the topic of this research. Among them is a book entitled Batik Klasik (Classic Batik) written by Hamzuri in 1994 which contains the technique of making and the types of batik motifs.

The book Batik Design (1997) written by Pepin Van Rooijen, in this book, contains a lot of pictures of batik patterns and motifs, a book that is almost the same as a book written by Santosa Doellah entitled, Batik The Impact Time and Environment (Batik The Impact Time and Environment), which reveals the decorative variety of classic motifs to Indonesian motifs; Other books to complement this literature review include:

1.The book entitled, Bathik Sebagai Busana Dalam Tatanan dan Tuntunan (Bathik as Clothing in Order and Guidelines) printed in 2002 written by Kalinggo Honggopuro contains the philosophy contained in batik and its description of the procedures and rules for wearing batik cloth;

2.An equally important book is entitled, De Inlandsche Kunstnyverheid in Nederlansche Indie, del III, De Batik Kunt S'Gravenhage (1916) written by Jesper Y.E., \& Mas Pringadie. Discussing about the variety of batik decorations that developed in Java to Madura;

3.Indonesia Indah "Batik" which was written by a joint team and then published by Yayasan Harapan Kita / BP 3 TMII, is a series of books published by Indonesia Indah about the background of the Indonesian nation's life, customs and cultural arts.

The various books that the author describes illustrate that these books are related to batik and its problems. At least it can provide the dynamic repertoire of science, especially regarding the world of batik.

\section{DISCUSSION}

\section{A. Structure and Arrangement of Gurda Motif}

\section{Identification of Gurda Motif}

Jesper and Mas Pirngadie in their book, De Inlandsche Kunstnyverheid in Nederlandsche Indie, explain that the Gurda motif can also be called Sawat, which is a motif depicting the shape of a bird with two broad left and right wings and has a long tail in the middle. (Jasper and Mas Pirngadie, 1916: 184) The bird in question is Garuda whose shape has been stylized. The Garuda is a mythological creature, halfhuman, half bird, which is a symbol and symbol that implies freedom ${ }^{4}$. This is related to the context of the mythological story, which is described as a child who frees his parents from the bondage of Dewi $\mathrm{Kadru}^{5}$ and the dragons. The same opinion was expressed by Tjokorda Udiana that the Garuda is often used as a symbol of various world societies as a symbol of power and liberation. Further explained related to Hindu and Buddhist mythology, Garuda is always contrasted with the dragon. Garuda has associated with the world above, especially the natural element, namely the sun. Dragons are associated with the underworld and are considered the rulers of the underworld (Tjokorda Udiana, 2013: 44).

\footnotetext{
${ }^{4}$ Interview with Timbul Haryono, a UGM archaeology expert on April 18, 2018

${ }^{5}$ In mythology, Kadru and Winata are two sisters, the wife of the Resi Kasiapa. Kadru has an adopted son of three snakes/dragons and Winata has an adopted son Garuda. The lazy Kadru feels bored and tired of having to take care of his three naughty adopted children because they often disappear between the bushes. Kadru had an evil intention to hand over this task to Winata. Winata invited Winata to bet on the tail of white horse Uraiswara which often passed their house and the loser had to comply with all orders of the winner. With trickery, Kadru finally managed to become the winner. Since then Winata was ordered to serve all Kadru's needs and take care of her three snakes every day. Winata then asked Garuda to help with these tasks.
} 
Garuda is often visualized in various decorative motifs, one of which is the batik cloth. In Garuda batik it is often referred to as Gurda, where the depiction cannot stand alone as a batik pattern but is the main motif in a pattern. The placement of the Gurda motif in the batik pattern is often used in semen, ceplok and lereng batik patterns. The stylization shape of the Garuda has many variations, but there is one that is described as the most complete, namely the wide right and left wings with a tail known as Sawat. This motif can only be used by Sinuwun (kings) which is called batik larangan (prohibited batik). Similar thoughts were also conveyed by Soerjanto in an interview as follows:

What is meant by Sawat batik is a picture in the form of right and left wings and has a tail which symbolizes the Garuda bird. All batik patterns that contain Sawat's pictures are included in the batik larangan (prohibited batik) group, both in batik semen patterns and other batik patterns if there is

Sawat then they are included as batik larangan. including batik pattern semen gedhe ${ }^{6}$.

The connotation of this statement gives a clearer picture that the Sawat motif can be said to be the motif which is the most complete depiction of the Garuda bird and cannot stand alone as a batik pattern but will be combined with other motifs.

The visualization form of the Garuda in batik, in addition to being depicted with two wings and a tail called Sawat, is also depicted with one wing without a tail which is a siring called mirong (Jasper and Mas Pirngadie, 1912: 184). Meanwhile, the form of Garuda with two wings without a tail is called elar. (Sri Soedewi Samsi, 2011: 95) Motifs depicting the Garuda bird in the world of batik are often found in semen patterns, ceplok patterns and lereng patterns as the main motif. However, it is also used as a nonessential motif but as a decorative interlude. In the following, it can be seen the difference between sawat, lar and mirong in the image below.

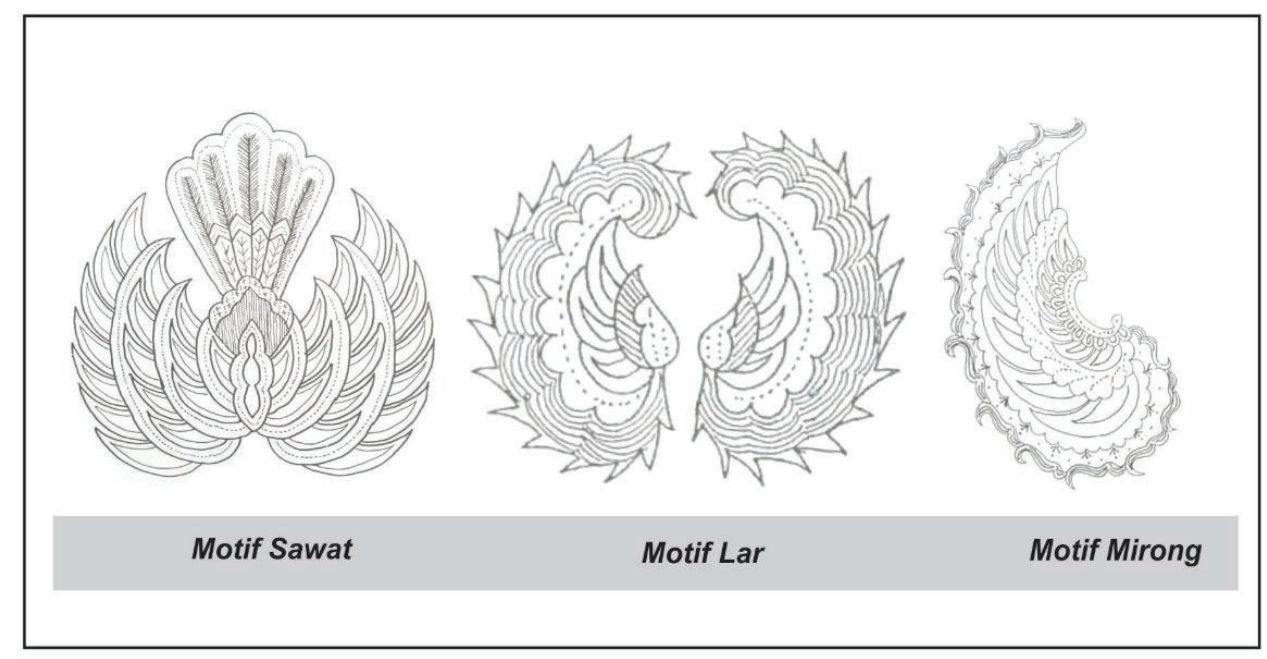

Picture 2. : Gurda motif images are divided into three types namely sawat, lar and mirong.

\section{Structure and Arrangement of Gurda Motifs in Classic Pattern Batik}

Gurda as the shape of the motif is structurally adjusted and in tune with the concept of forming the motif. Batik motifs can be formed when there is one or more point-line-plane or point-line or point-plane or line-plane or point or line or plane, then arranged to form an object based on the strongest character of the object, a motif will be formed in the arrangement of patterns batik. The dominant motive for batik that becomes the centre of attention is usually referred to as the main or main motif.

In the batik decoration, there is a pattern structure. The structure of the batik pattern is the structure or basic principle of the preparation of batik. (Dharsono, 2007: 87) Dharsono further explained that the structure of the batik pattern consists of an arrangement of motifs which are classified into three, namely: the main motif is the main element of the pattern, in the form of a picture of the shape of a particular object, because it is the main element, it can be called the main motif (principal). Then the second is the Supporting motif, which is a motif in the form of pictures made to fill the space, a shape smaller than the main motif. This motif can also be called a filler motif (selingan). The three Isen-isen motifs are motifs that function to beautify the overall pattern, both the main and filler motifs are filled with decorative dots, lines, a combination of dots and lines. Usually, isen in batik art has a certain form and name, in large numbers. Of the three motif calcifications, the main motif is the motif that plays the most important role

\footnotetext{
${ }^{6}$ Soerjanto, Curator of the Danar Hadi Ancient Batik Museum, Interview, 15 March 2008
} 
as the main theme of the idea of creation. The arrangement of the motifs which consists of the main motif, the supporting motif and the isen motif when composed in such a way can be called a pattern. Pattern batik consists of two types, namely, classic pattern batik, namely the workmanship of batik as a whole which still refers to classical batik with batik techniques using synthetic dyes. Then the second is batik creation patterns, namely batik making no longer completely (not completely) refers to classical batik, colouring techniques and free batik techniques. Darsono explained that both classical pattern batik and creative pattern batik can be said to be imitation batik (Javanese: tiron). The use of the name batik pattern is often added with a suffix -an which means an imitation of the classic batik referred to, for example, srikatonan, sidomukten, truntuman, sawatan, gurdhan and so on. (Dharsono, 2005: 149).

Related to the structure and arrangement of Gurda motifs in classical pattern batik, in this study the authors selected several batik patterns, including semen rama pattern batik, semen remeng latar putih pattern batik, srikaton pattern batik, Surakarta sido mukti pattern batik, lung-lungan babon angkrem pattern batik. The interesting thing about classic batik patterns is that Gurda motifs are often found, either in the form of mirong, lar or sawat. In a similar vein, Sri Soedewi Samsi stated that Garuda decorations are often used in batik patterns and are very likely to be combined with other decorative styles in fine, medium and printed batik. (Soedewi Samsi, 2011: 95). The following is the arrangement of Gurda motifs on classic batik patterns that the authors have mentioned above.

a) Semen Rama Batik Pattern

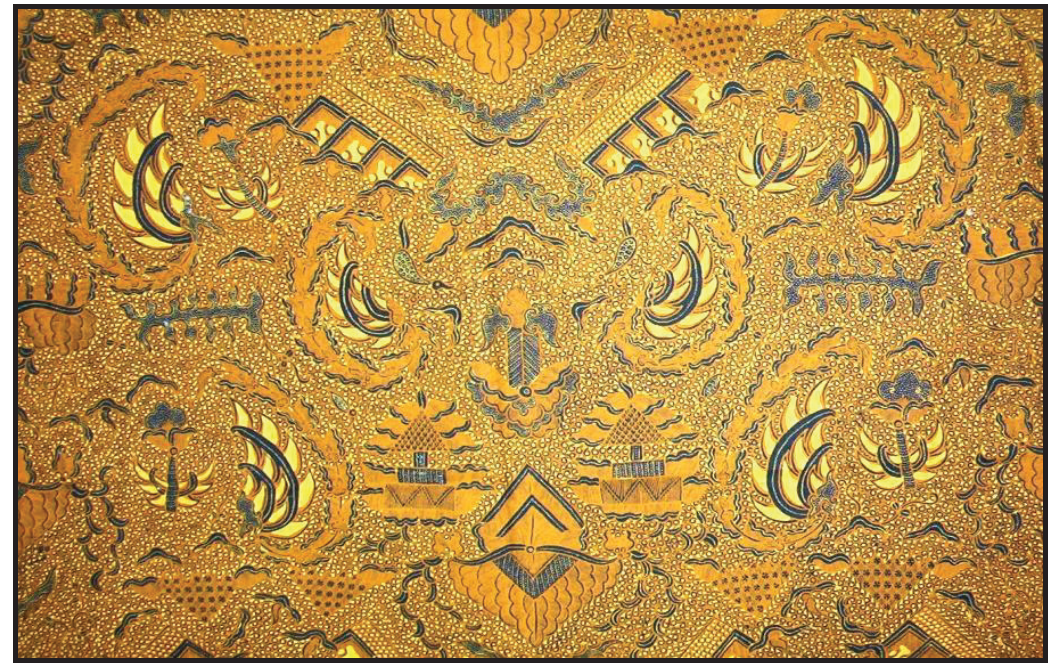

Picture 3. : Image of semen rama batik pattern from Surakarta, with Gurda motif depicted with a mirong shape that surrounds the motif of the pohon hayat (tree of life) along with other main motifs. (Photo

Dharsono repro, 2005: 116)

The batik pattern of semen rama (ramawijaya) consists of several main motifs, namely the Gurda mirong motif, the dampar motif, the pusaka (heirloom) motif, the baito/ship motif, the bird motif, the pohon hayat (tree of life) motif, the flame motif, the meru motif and the animal motif. It is a form of repetition of 9 main motifs or often called $8+1$ main motifs, which Dharsono explains as Hastabrata teachings, namely the teachings of the sacred that reflect Javanese cultural expressions. This view contains a philosophical discourse about the portrait of a wise leader who prioritizes state interests over personal interests (Dharsono, 2005: 117)

The arrangement of the semen rama batik pattern is a combination of the main motifs which have an essential meaning that is teaching aimed at and implied to the king or the leadership of the people, which is symbolized in the dampar ornament as a symbol of power (Sewan Susanto 1980: 235). The selingan (intermittent) motif in the form of geometric lines combined with the lung-lungan motif is a filling element, as part of the arrangement of batik as well as to form a balance in composition. As a whole, it provides unity in the arrangement of batik patterns. The isen (stuffing) motif consists of a cecek (dots) combined with a line applied to the main batik motif or on an interlude is a variation to give batik a beautiful taste. 
b) Semen Remeng Latar Putih (White Background) Batik Pattern

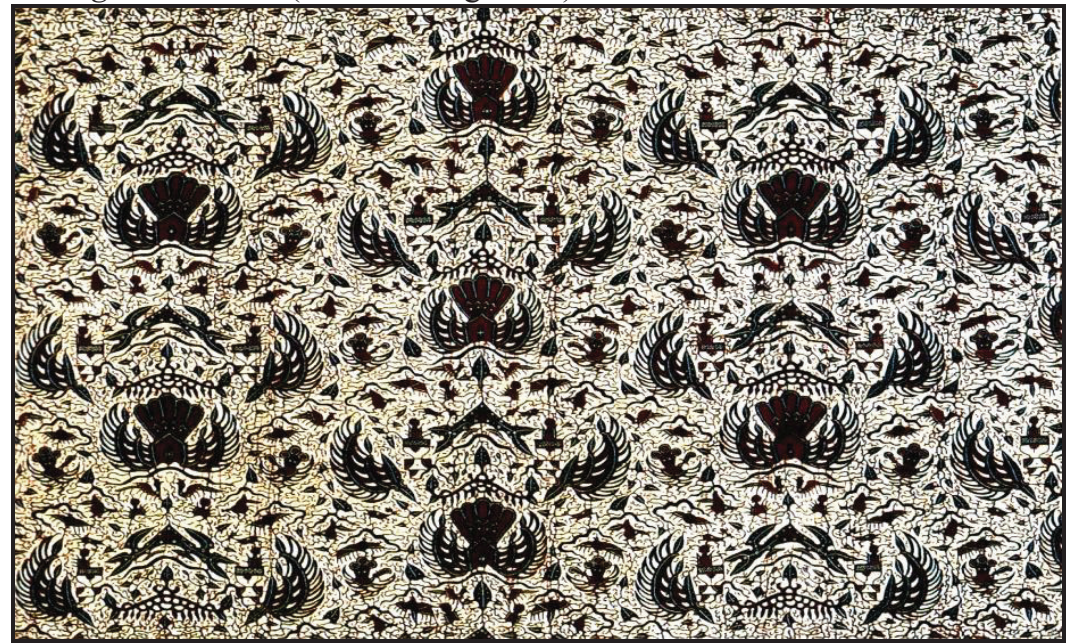

Picture 4. : Image of Semen Remeng Batik Pattern, gurda motif depicted in mirong and sawat forms that seem to dominate. (Photo repro Santosa Doellah, 2002: 27).

Batik Semen Remeng Latar Putih (white background), structurally it is a combination of five main motifs, namely the motif of the pohon hayat (tree of life), Gurda, bird, building and meru. The motif of the Gurda is depicted as dominating and depicted in the form of mirong and sawat. The pattern is arranged in the position of a pohon hayat combined with a meru motif flanked by a pair of Gurda motifs and a pair of bird motifs in a flying position, on the right-left upper and upper sides there is a building motif on which there is a meru motif combined with a bird motif. The alternating motif is in the form of lung-lungan motifs that variously decorate the space. Overall, the selingan motif and the main motive are building a unity pattern of batik arrangement. While the isen motif (stuffing) consists of cecek (dots) combined with a line applied to the main motif or on an selingan interlude.

c) Srikaton Batik Pattern

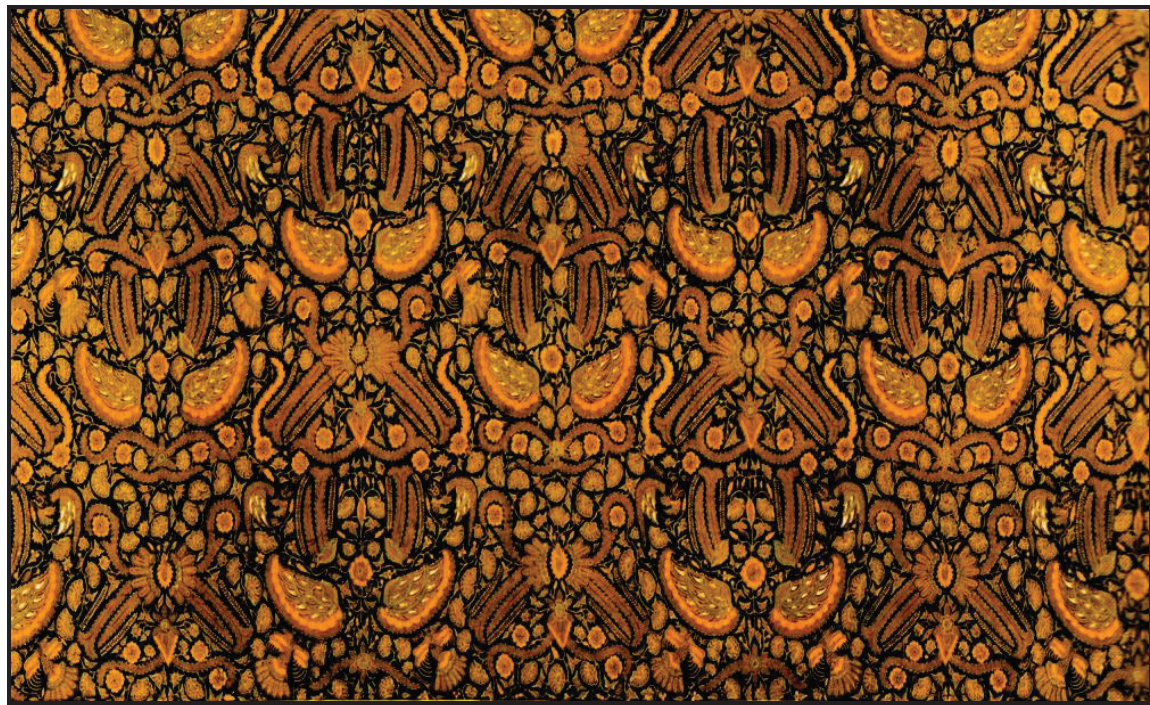

Picture 5. : Image of Srikaton Batik Pattern, a motif of Gurda from lar type appears to seem bigger than the other motifs. The main motif arrangement consists of of 8 motifs composed of 2 patterns. The main motif is in the form of a pohon hayat (tree of life motif), Gurda motifs, srikaton flower motifs, snake motifs, bird motifs. (Photo Dharsono repro, 2005: 149)

Srikaton Batik Pattern is a classic batik which is often called Srikatonan batik. The structure in Batik Srikaton, consists of 8 motifs arranged by 2 patterns (main motif arrangement) which are arranged in a repetitive (repetitive) manner. Pattern 1 is a pohon hayat motif flanked by a pair of perched bird motifs, a pair of snake motifs, a pair of srikaton flower motifs, and the lower part is flanked by a pair of Gurda motifs of the lar type. Pattern 2 in the form of a pohon hayat motif is enclosed by a pair of srikoton flower motifs in bloom, on top flanked by a pair of bird motifs in a flying position and the top is flanked by a pair of Lar (Garuda) motifs. Pattern 1 and pattern 2 are arranged repeatedly. Selingan (Interlude) motifs in the form of ceplok and strands that decorate the space between the main motifs and at the same 
time strengthen the balance of the composition. As a whole, it provides unity in the arrangement of batik patterns.

d) Sidomukti Batik Pattern

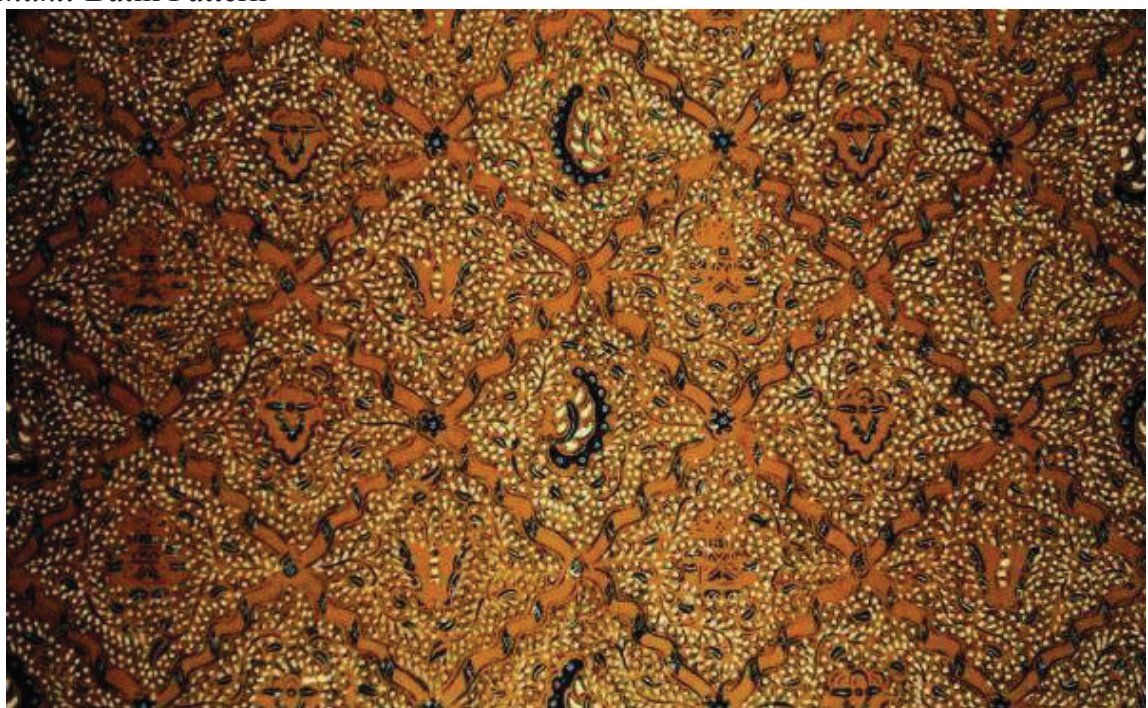

Picture 6. : Sidomukti Batik Pattern, the main motif consists of Gurda motif, pohon hayat (tree of life) motif, dampar motif, building motif. The motif of the Gurda is described as the mirong. (Source of Photo is downloaded from https://javanist.com/motif-batik-sidomukti-surakarta)

Batik Sidomukti means to get the glory, the meaning of the word is reflected through the motifs found in Sidomukti batik. Contains teachings about the glory of life that people believe in the gifts bestowed by God. Sidomukti pattern batik, arranged based on a basic geometric pattern consisting of 4 main motifs forming square planes, each area filled with motifs of pohon hayat (tree of lifes), dampars, buildings, and Garuda.

According to Dharsono, the sidomukti batik pattern is formed by two patterns. Pattern 1 depicts a pohon hayat (tree of life) pattern as if it is surrounded on the top and bottom flanked by a pair of Garuda motifs, and the middle part is flanked by a pair of buildings. Pattern 2 depicts the pattern of the pohon hayat (tree of life) as if it is surrounded by a top and bottom flanked by a pair of Garuda motifs, and the middle is flanked by a pair of dampars or butterflies. As a whole, the pohon hayat (tree of life) is surrounded by other motifs as if to maintain its existence. (Dharsono, 2005: 119)

e) Babon Angrem Batik Pattern

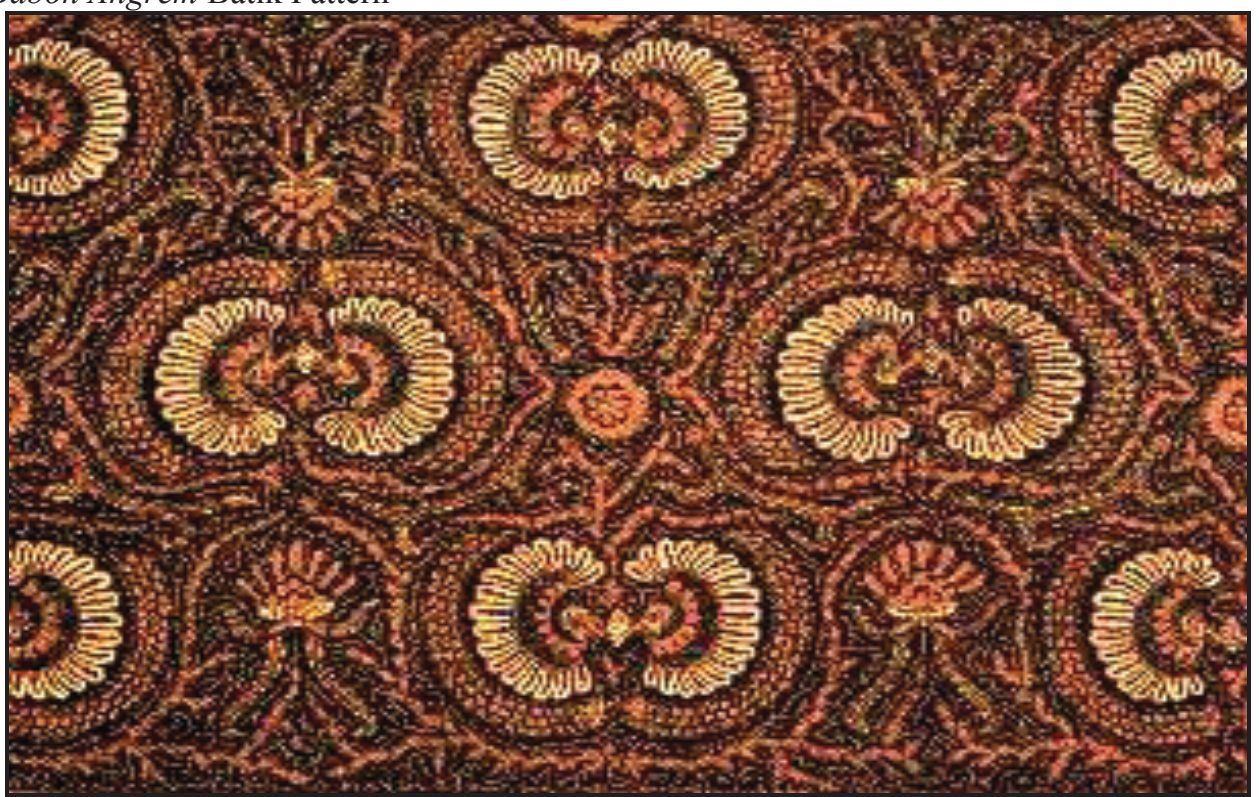

Picture 7. : Babon Angrem Batik Pattern, consisting of the main motif in the form of a Gurda motif lar types, ceplok flower motifs, pohon hayat (tree of life) motifs and human motifs. (Photo repro Santosa Doellah, 2002: 28)

The batik structure of the babon angrem pattern is formed by repetition or repetition of the flower ceplok 
motif, the pohon hayat (tree of life) motif interspersed with the Garuda motif lar type which resembles a babon (a hen) incubating eggs. Below right-left and above right-left are human motifs. The selingan motif in the form of a wavy lung line motif adjusts the main motif. As a whole, the combination of the main motive and the selingan motif forms a unity. The isen motif consists of cecek combined with lines applied to the main batik motif or at selingan or in empty spaces as a variation.

\begin{tabular}{|c|c|c|}
\hline Batik Name & Main Motive & Information \\
\hline $\begin{array}{ll}\text { Semen Ramawijaya } \\
\text { Batik }\end{array}$ & $\begin{array}{l}\text { It consists of several main motifs, namely mirong } \\
\text { type Gurda, dampar motif, pusaka (heirloom) motif, } \\
\text { baito/ship motif, bird motif, pohon hayat (tree of life) } \\
\text { motif, flame motif, meru motif, and animal motif. Is } \\
\text { a form of repetition of } 9 \text { main motifs or often called } 8 \\
+1 \text { main motif. }\end{array}$ & $\begin{array}{l}9 \text { main } \\
\text { motives }\end{array}$ \\
\hline $\begin{array}{l}\text { Semen Remeng Latar } \\
\begin{array}{lr}\text { Putih } & \text { (white } \\
\text { background) Batik } \\
\text { Pattern }\end{array}\end{array}$ & $\begin{array}{l}\text { Pohon hayat (tree of life), Garuda, meru, buildings, } \\
\text { birds. }\end{array}$ & $\begin{array}{l}5 \\
\text { motives }\end{array}$ \\
\hline $\begin{array}{ll}\text { Srikaton } & \text { Batik } \\
\text { Pattern } & \end{array}$ & $\begin{array}{l}\text { Pattern 1: Pohon hayat (tree of life), Garuda, snake, } \\
\text { bird, srikaton flower. } \\
\text { Pattern 2: Pohon hayat (tree of life), Garuda, bird, } \\
\text { srikaton flower. }\end{array}$ & $\begin{array}{l}\text { Pattern 1: } \\
5 \quad \text { main } \\
\text { motives } \\
\text { Pattern 2: } \\
4 \quad \text { main } \\
\text { motives }\end{array}$ \\
\hline $\begin{array}{l}\text { Sidomukti } \\
\text { Pattern }\end{array}$ & $\begin{array}{l}\text { Pattern 1: The top and bottom part of the Pohon } \\
\text { hayat (tree of life) pattern is flanked by a pair of } \\
\text { Garuda motifs, and the middle part is flanked by a } \\
\text { pair of buildings. } \\
\text { Pattern 2: The top and bottom part of the Pohon } \\
\text { hayat (tree of life) pattern is flanked by a pair of } \\
\text { Garuda motifs, and the middle is flanked by a pair of } \\
\text { dampar. }\end{array}$ & $\begin{array}{l}4 \\
\text { motives }\end{array}$ \\
\hline $\begin{array}{l}\text { Babon Angrem Batik } \\
\text { Pattern }\end{array}$ & $\begin{array}{l}\text { Flower, Pohon hayat (tree of life), Gurda, human } \\
\text { motif }\end{array}$ & $\begin{array}{ll}4 & \text { main } \\
\text { motives } & \end{array}$ \\
\hline
\end{tabular}

Picture 8. : Mapping table of the formed batik pattern arrangement of the composition of the main motive elements.

\section{B.Gurda Motif Variations}

In the previous discussion, it was known that there are three types of Gurda motifs, namely sawat, mirong and lar. In the next discussion, we will discuss the various forms of Gurda motifs. There are two variations of the sawat type Gurda motif which can be said to be original referring to the findings of the field data and literature review that has been carried out, namely the sawat motif can be divided into three. The seven sap wings, five sap wings, and nine sap wings each have the same tail, namely five sap. Both also have the same inner and outer wings. Likewise for the mirong and lar types, both are wing shapes with five sap wings, seven sap wings, and nine sap wings without a tail.

As for the variations, there are many variations, but in general, it still shows a strong main character, namely the wings with layers. Then the writer pulls the red thread, showing an odd number of five, seven and nine. In this part of the body, the tail often experiences many variations, which is an illustration of where the tail feathers are embedded. Sawat motif is a picture of a flying Garuda seen from behind so that the body of the tail as the central part of the centre is depicted as a circle as a picture of the anus, However, in the development, the variations are sometimes not clearly illustrated and even non-existent. In the following, the author displays the motive of the sawat with various variations that the author managed to collect. 


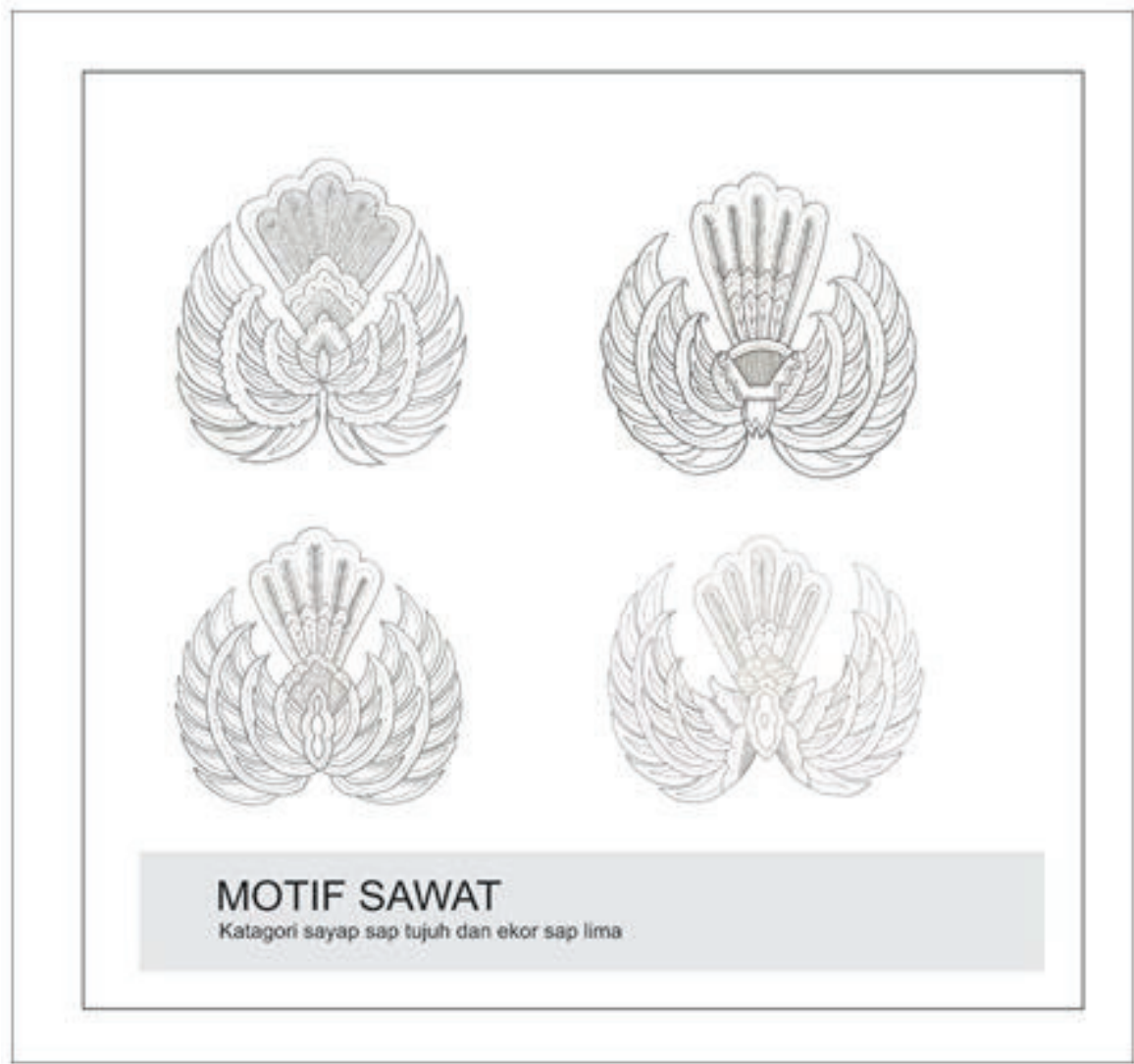

Picture 9. : Drawing of variation of sawat motif with the outer wing category with seven wings, the outline is almost the same, which distinguishes only the part of the body where the tail is embedded.

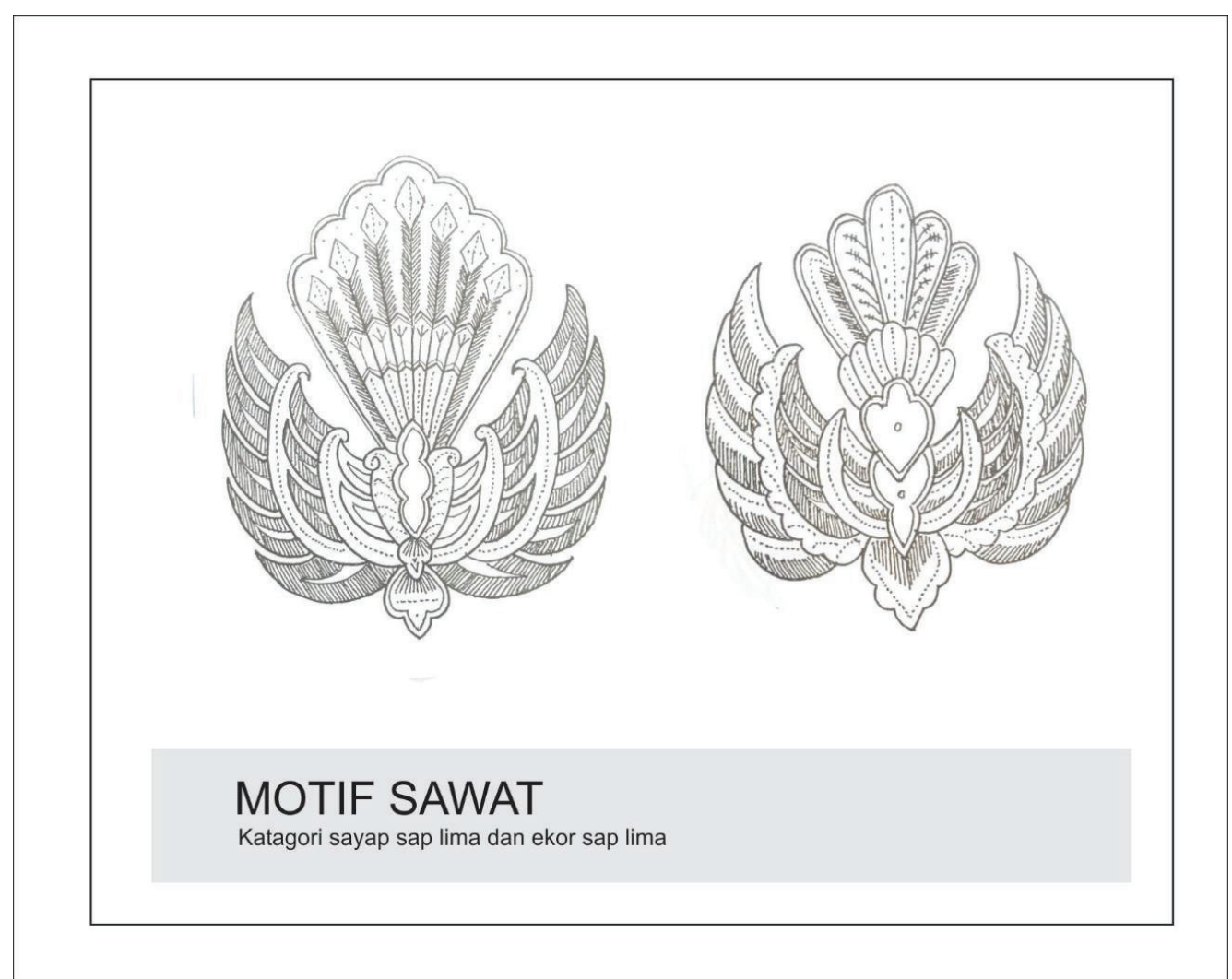

Picture 10. : Image of variation of sawat motif with five winged outer wing category, the outline is almost the same which distinguishes only on the part of the body where the tail is embedded. 
As for the variation of lar and mirong, it can be seen in the following figure

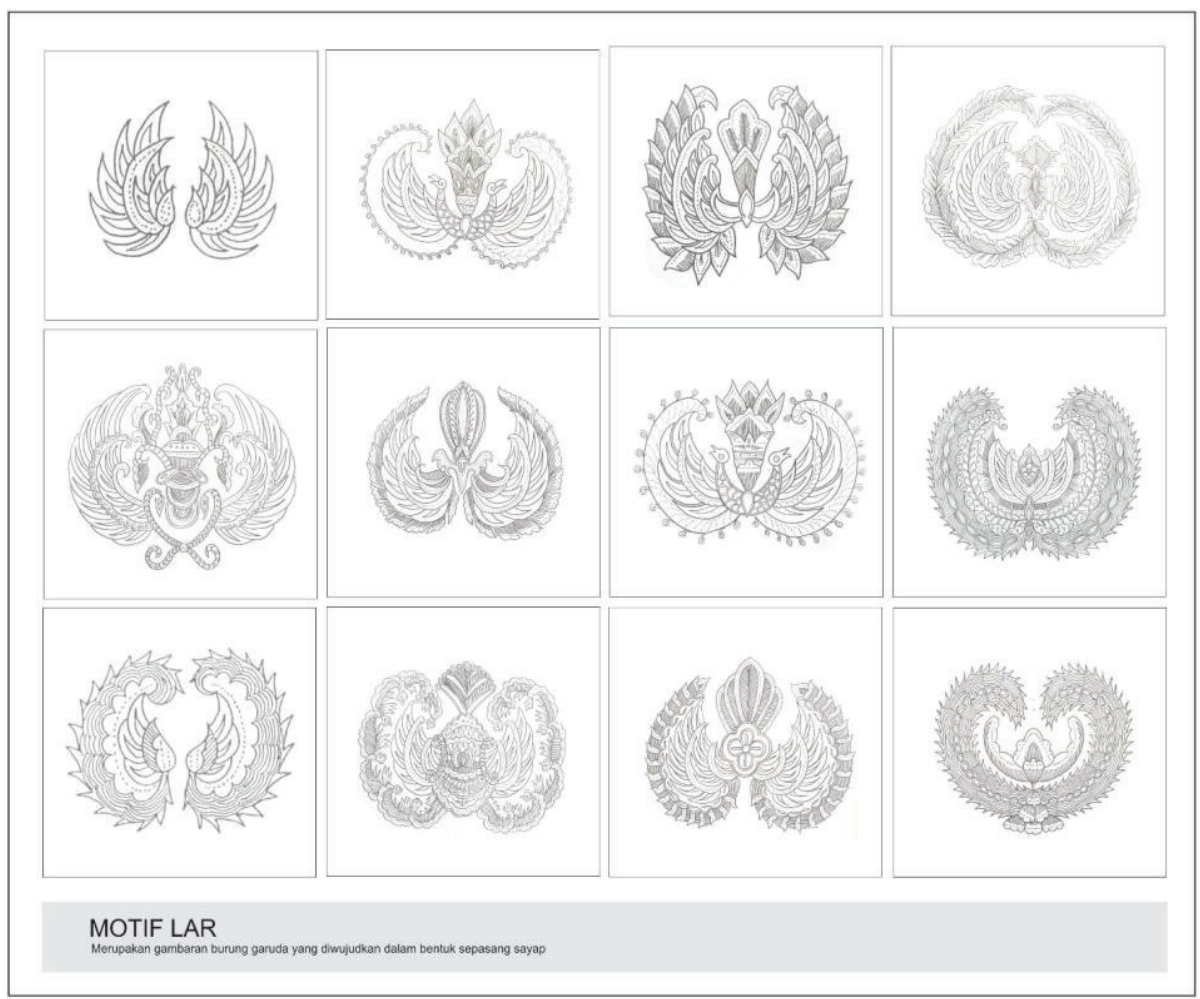

Picture 10. : Image of variation of lar motif with the category of open-winged wings, half-open wings on the sides of each wing arranged with a closed wing motif, and a pair of wings with a closed wing motif. The outline is almost the same is described as a pair of wings.

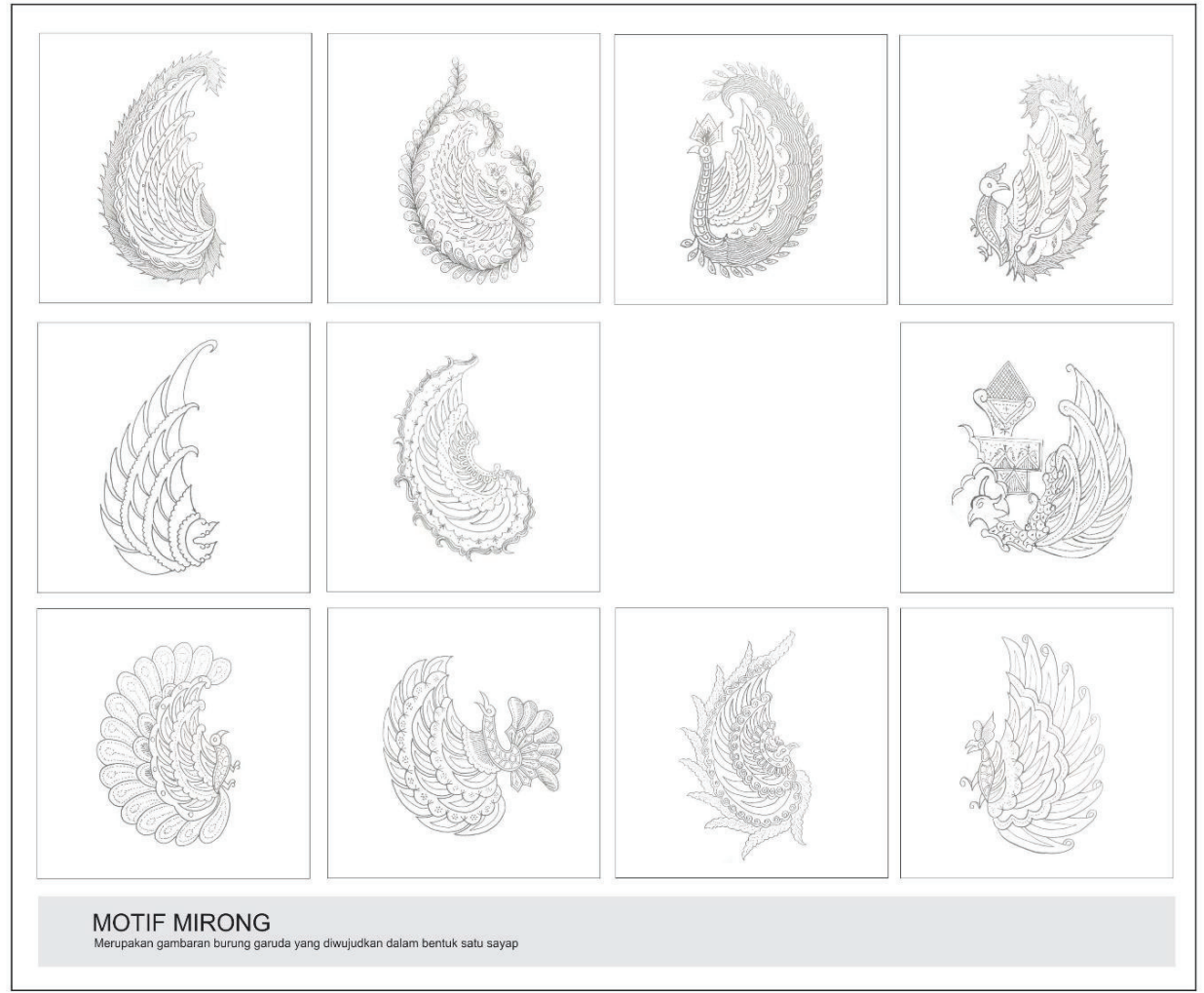

Picture 11. : The mirong motif variation image is represented by one half-open wing with an open wing category, and an open wing category with the edges of each wing arranged with a closed wing motif. The outline is almost the same, as if a bird perching is seen from the side. 


\section{CONCLUSION}

From the description that has been described, it can be concluded that the arrangement of Gurda motifs in batik can be divided into three. Namely, the sawat motif which is depicted with two open wings with sap wings and a five-winged tail, which is a depiction of an eagle spreading its wings from behind. Placed on batik, the sawat motif is used as the main motif combined with other motifs such as lereng, ceplok and semen patterns. Then the second, lar motif, is a form of a pair of wings which can be divided into three categories, namely open wing wings, half-open wings on the sides of each wing arranged with a closed wing motif, and a pair of wings with a closed wing motif. The shape is roughly the same as the most prominent and dominant character lies on the two opposite wings. Placement in lar motif batik is used as a main or alternating motif that is often found in semen patterns. In the lereng and ceplok pattern lar motifs are used as the main motifs such as the parang ceplok gurda and truntum ceplok gurda.

Furthermore, the third mirong motif is a depiction of Garuda with one open wing. There are two categories, namely mirong with open wings only, and mirong with open wings with the edges of each wing arranged in a closed wing motif. The shape is roughly the same as if a perch is seen from the side view with the wings as its strongest character. Arrangement in batik, lar motif is used as a main or interlude motif that is often found in semen patterns.

As for the structure of the Gurda motif, it can be concluded that the structure of the Gurda motif is mainly formed from the wing element. Which can be differentiated into open wings and closed wings. Especially for the sawat motif, only an open wing with a sap-wing structure is used, consisting of an inner, middle and outer wing. On the outer wings, there are seven but some are numbered five and nine. It is a visual form of Garuda with a special character that is formed by people's perceptions of a long journey of form transformation.

\section{BIBLIOGRAPHY}

Bates, Kenneth F. 1986 Basic Design (Principle and Practice) USA : The World Publishing Company

Dharsono, 2007, Budaya Nusantara, Bandung : Rekayasa Sain

Darsono, 2005, Pohon Hayat : Simbol dan makna pohon hayat yang terlukis pada batik klasik sebagai ekspresi kebudayaan Jawa., Desrtasi., Institut Teknologi Bandung (ITB)

Fowler, H.J. and Fowler, F.G., 1964., The Concice oxford Dictionary., London : Oxford University Press

Jasper, J.E. dan Mas Pirngadie, Kerajinan Pribumi di Hindia Belanda. (Terj) Gravenhage : De boek \& Kunstdrukkerij V/N Mouton \& Co, 1916

Leedy, Practical Research: Planing and Design, Merrill-Prentice Hall, New Jersey., 1997

Susanto, Sewan, ., Seni Kerajinan Batik Indonesia, Jakarta : Balai Penelitian Batik dan Kerajinan Lembaga Penelitian dan Pendidikan Industri, Departemen Perindustrian RI., 1980

Sudarwanto, Aan. 2012, Batik dan Simbol Keagungan Raja, Surakarta: Citra Sain LPKBN

Soedewi, Sri., 2007., "Motif, Proses dan Tekhnik Pembatikan." Makalah Seminar Batik Nusantara. dalam Festifal Batik Nusantara 2007

Sutopo, HB. 2006., Metodologi Penelitian Kualitatif Dasar Teori dan Terapanya dalam Penelitian., Surakarta: Penerbit Universitas Sebelas Maret

Tokiyo dan Sukarman., 1981., "Pengantar Kuliah Ornamen”., Yogyakarta : STSRI "ASRI"

Udiana, Tjokorda NP. 2013, Garuda Bali Prespektif Cultural Studies., Denpasar : Cakra Press 